\title{
Pengaruh perubahan diameter pipa mendadak 1 inch ke $3 / 4$ dan 1 1/4 inch terhadap pressure drop dengan variasi bukaan katup
}

\author{
Muhammad Taufiq Afifudin ${ }^{1^{\star}}$, Basuki², Mohammad Arif Irfa' ${ }^{3}{ }^{3}$ \\ ${ }^{1}$ Program Studi Teknik Mesin, Fakultas Teknik, Universitas Hasyim Asy'ari Jombang \\ Jl. Irian Jaya No. 55, Tebuireng, Cukir Kec. Diwek Kab. Jombang \\ 2, 3Jurusan Teknik Mesin, Fakultas Teknik, Universitas Hasyim Asy'ari Jombang \\ Jl. Irian Jaya No. 55, Tebuireng, Cukir Kec. Diwek Kab. Jombang \\ ${ }^{*}$ Corresponding author: m.taufiqafifudin@gmail.com
}

\begin{abstract}
Application of the principles of fluid mechanics can be found in the fields of industry, transportation and households. The series of PVC pipes that are used to distribute water at home, of course, has losses caused by its components, one of which is the change in the crosssection of the pipe. One of the energy losses in the change in pipe section is the pressure drop. The pressure drop can be influenced by the fluid flow discharge and the magnitude of the change in the pipe, dibit has fluid flow which causes pressure on the pipe wall. The research in this thesis was carried out in the Mechanical Engineering Laboratory of the Hasyim Asy'ari University. This research is quantitative in nature which will discuss the pressure drop in the sudden change in cross-section which has a diameter of 1 inch to 3/4 inch and 1 inch to $11 / 4$ inch with variations in valve openings of $100 \%, 75 \%$ and $50 \% .1$ inch to $3 / 4$ inch at each valve opening is $100 \% 0.1$ bar, $75 \% 0.09$ bar and $50 \% 0.05$ bar, while the pressure drop of 1 inch cross section change at each valve opening is $100 \%$ equal to 0.03 bar, $75 \%$ at 0.03 bar and $50 \%$ at 0.06 bar.
\end{abstract}

Keywords: Pressure drop, change in pipe diameter, valve opening, fluid mechanics

\begin{abstract}
Abstrak
Penerapan prisip-prinsip mekanika fluida dapat dijumpai pada bidang industri, transportasi dan rumah tangga. Rangkaian pipa PVC yang digunakan untuk mendistribusikan air di rumah, tentunya memiliki kerugian- kerugian yang diakibatkan oleh komponenkomponennya, salah satunya pada perubahan penampang pipa. Salah satu kerugian energi pada perubahan penampang pipa yaitu penurunan tekanan. Penurunan tekanan dapat dipengaruhi oleh debit aliran fluida dan besarnya perubahan pipa tersebut, dibit memiliki aliran fluida yang mengakibatkan tekanan pada dinding pipa. Penelitian dalam skripsi ini dilaksanakan di laboratorium Teknik Mesin Universitas Hasyim Asy'ari. Penelitian ini bersifat kuantitatif yang akan membahas tentang penurunan tekanan pada perubahan penampang mendadak yang memiliki diameter 1 inci ke $3 / 4$ inci dan 1 inci ke $1 \frac{1}{4}$ inci ini dengan variasi bukaan katup $100 \%, 75 \%$ dan 50\%.Hasil Penelitian penurunan tekanan perubahan penampang pipa 1 inci ke $3 / 4$ inci pada setiap bukaan katup yaitu $100 \%$ sebesar 0,1 bar, $75 \%$ sebesar 0,09 bar dan $50 \%$ sebesar 0,05 bar, sedangkan penurunan tekanan perubahan penampang $1 \frac{1 / 4}{4}$ inci pada setiap bukaan katup yaitu $100 \%$ sebesar 0,03 bar, 75\% sebesar 0,03 bar dan $50 \%$ sebesar 0,06 bar.

Kata kunci: penurunan tekanan, perubahan diameter pipa, bukaan katup, mekanika fluida.

\section{Pendahuluan}

Lingkungan di sekitar kita tidak akan jauh dari fluida untuk memenuhi kebutuhan hidup. Fluida tersebut merupakan zat yang dapat dengan mudah kita jumpai, contohnya

yaitu udara sebagai sumber pernafasan makhluk hidup dan air sebagai sumber mineral makhluk hidup. Fluida dapat diartikan sebagai zat yang bisa berubah bentuk sesuai dengan bidang atau bentuk
\end{abstract}


yang dialirinya secara terus menerus. Penerapan fluida dapat dijumpai pada bidang transportasi, industri dan sebagainya. Kegunaan fluida yang sudah begitu penting membuat hal tersebut perlu di kaji lebih dalam, dimana fluida dalam pipa memiliki kerugian yang mengakibatkan aliran fluida tersebut kurang maksimal. Bentuk-bentuk kerugian energi pada aliran fluida dapat dijumpai pada aliran dalam pipa. Kerugian tersebut diakibatkan oleh gesekan fluida dengan dinding pipa dan juga komponen yang terdapat pada sistem perpipaan tersebut.

Mekanika fluida merupakan ilmu yang digunakan untuk mempelajari hal-hal yang terjadi pada fluida. Fluida dapat dibedakan menjadi dua zat yaitu zat cair dan zat gas. Fluida gas merupakan zat yang memiliki partikel-partikel yang tidak rapat sehingga dapat termampatkan, sedangkan fluida cair merupakan zat memiliki partikelpartikel rapat sehingga fluida ini tidak bisa termampatkan. Komponen pada sistem perpipaan yaitu percabangan, belokan pipa, sambungan pipa, katup-katup, pembesaran dan pengecilan pipa. Pembesaran penampang dan pengecilan penampang pipa mengakibatkan kerugian yang terjadi karena kontraksi fluida dengan dinding pipa yang mengalami perubahan besar bidang. Kerugian tersebut juga mengakibatkan perbedaan tekanan yang terjadi antara sebelum dan sesudah komponen pipa, sehingga terjadi penurunan tekanan atau pressure drop. Sehingga dengan dasar mekanika fluida, dapat diketahui pemecahan masalah tentang kerugian penurunan tekanan akibat perubahan penampang yang terjadi pada sistem perpipaan.

Penelitian sebelumnya tentang eksperimental karakteristik pressure drop pada sambungan $\mathrm{T}$ (Tee) contraction untuk posisi searah dengan variasi sudut kemiringa, menyimpulkan pada aliran fluida sebelum memasuki sambungan (tee) contraction dengan variasi sudut kemiringan mengalami peningkatan pressure drop yang sama. Hal tersebut dipengaruhi oleh faktor gesekan pada aliran pipa yang lurus horizontal. Selain itu, pressure drop akan memiliki nilai yang semakin besar apabila luas penapang aliran fluida mengalami perubahan semakin kecil. Hal tersebut dipengaruhi oleh faktor gesekan yang terjadi pada diding pipa yang mengecil. Semakin kecil penampang yang dialiri fluida maka faktor gesekannya juga kecil [1].

Penelitian berikutnya tentang eksperimental karakteristik pressure drop pada pipa dan variasi elbow $90^{\circ}$ untuk sistem perpipaan menyimpulkan peningkatan bilangan Reynolds pada pipa vertikal menyebabkan karakteristik pressure drop juga mengalami peningkatan. Hal ini disebabkan elevasi yang dominan dibandingkan dengan faktor gesekan. Karakteristik pressure drop pada elbow $90^{\circ}$ yang mempengaruhi peningkatan secara signifikan, akibat bentuk dimensi dari elbow yang menyebabkan adanya perbedaan ketinggian (elevasi), dimana elevasi lebih tinggi menghasilkan pressure drop lebih tinggi dibandingkan dengan elevasi yang rendah. Karakteristik pressure drop pada pipa horizontal sampai jarak $10 \mathrm{D}$ pada pipa horizontal yang menggunakan elbow short yang mendominan adalah pada elbow, dibandingkan faktor gesekan. Sedangkan karakteristik pressure drop pada pipa horizontal sesudah jarak $10 \mathrm{D}$ pada pipa horizontal dengan penggunaan elbow short maupun elbow long faktor gesekan yang lebih dominan. Penelitian tersebut menginformasikan tentang pressure drop pada pipa dan variasi elbow $90^{\circ}$, tetapi belum menginformasikan tentang sambungan $\mathrm{T}$ (tee) terhadap pressure drop [2].

Penelitian lain juga pernah dilakukan yakni tentang pengaruh rasio diameter pipa terhadap perubahan tekanan pada bernoulli theorem apparatus menyimpulkan rasio diameter berpengaruh terhadap perubahan tekanan dan pengaruhnya adalah semakin besar rasio diameter maka tekanan menjadi besar. Hasil penelitian tekanan maksimum terjadi pada debit 0,0192 lt/dt di titik pengukuran 1 pada rasio 0,67 . Tekanan minimum terjadi pada 
variasi debit $0,0247 \mathrm{lt} / \mathrm{dt}$ di titik pengukuran 5 pada rasio 0,33 [3].

\section{Metode Penelitian}

1. Rancangan Penelitian

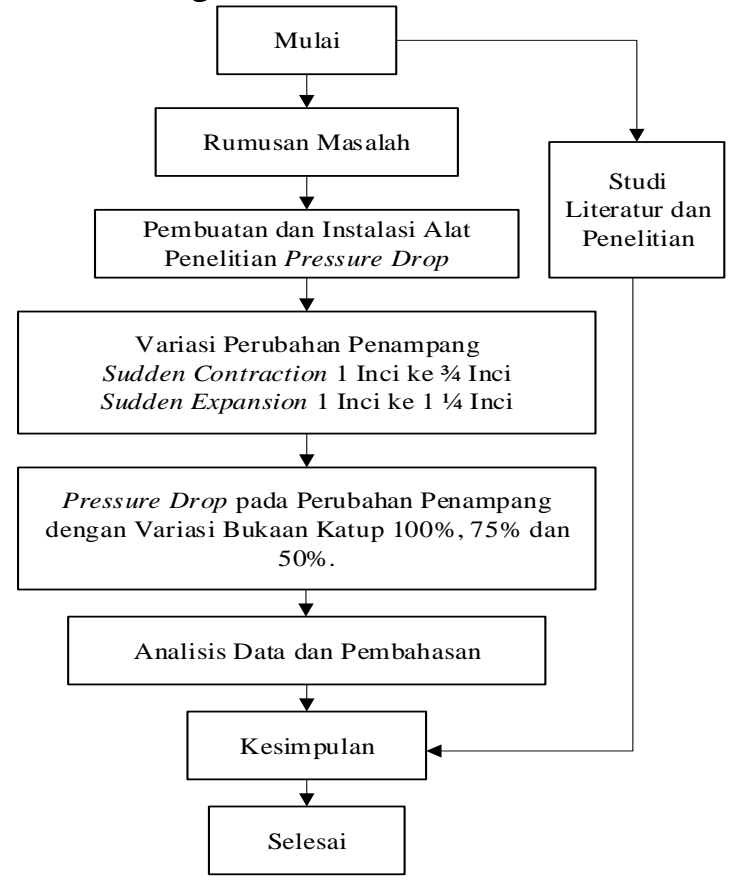

Gambar 1. Rancangan Penelitian

2. Variabel Penelitian

Penelitian ini memiliki variabel bebas yaitu variasi diameter perubahan pipa 1 inci ke 3/4 inci dan 1 inci ke 1 1/4 inci, dimana variabel bebas dapat mempengaruhi penelitian dan menjadi sebab perubahan variabel terikat. Variabel terikat penelitian ini yaitu penurunan tekanan atau pressure drop, dimana variabel terikat merupakan hasil dari variabel bebas. Variabel kontrol penelitian ini yaitu variasi bukaan katup $100 \%, 75 \%$ dan $50 \%$ dan volume air reservoir, dimana variabel ini merupakan variabel yang di atur, dikontrol dan dikendalikan sehingga pengambilan datanya valid dan hasilnya sesuai rencana.

\section{Teknik Pengumpulan Data}

Tahap pertama yang dilakukan dalam penelitian ini yaitu studi literatur, dimana dilakukan metode untuk mendapatkan bahan-bahan penelitian yang dapat digunakan sebagai acuan melakukan penelitian dengan cara menpelajari jurnal- jurnal atau buku-buku yang relevan dengan bidang penelitian.

Penelitian ini menggunakan metode pengumpulan data secara eksperimen, metode eksperimen adalah suatu metode yang dilakukan dengan cara melakukan suatu eksperimen guna mendapatkan suatu data yang valid dan sesuai dengan yang dibutuhkan. Maka dari itu perlu dilakukan perancangan alat untuk melakukan penelitian ini. Penelitian ini menggunakan alat yang dirancang dari kerangka alat, sambungan sistem perpiaan dan sambungan tee untuk tempat alat ukur tekanan yang diletakkan pada sebelum dan sesudah perubahan penampang. Setelah itu, terdapat katup setelah tee sesudah perubaan penampang yang jaraknya 3 kali diameter pipa untuk mengontrol debit.

Pada tahap sebelum pengambilan data dilakukan percobaan alat uji pressure drop dengan melihat aliran pada pipa keluaran terlihat stabil dan kalibrasi alat ukur yang akan digunakan untuk mengukur tekanan sebelum dan sesudah perubahan penampang pipa serta persiapan pada katup yang akan divariasi diposisikan membuka sebesar 100\%, 75\% dan 50\%. Setelah persiapan dilakukan maka dapat dilakukan proses penelitian dan mencatat data yang ditampilkan alat ukur pressure gauge pada tee sebelum dan sesudah perubahan penampang pada setiap bukaan katup yang telah divariasi $100 \%$ 75\% dan 50\%. Setelah mendapatkan data dilakukan perhitungan penurunan tekanan dengan persamaan berikut [4]:

$$
\Delta \mathrm{p}=\mathrm{p}_{1}-\mathrm{p}_{2}
$$

\section{Teknik Analisis Data}

Penelitian ini menggunakan teknik analisis data statistik deskriptif yang merupakan teknik untuk mendeskripsikan atau menyampaikan hasil penelitian dalam bentuk gambar grafik. Data yang diambil dalam penelitian ini yaitu tekanan pada sesudah dan sebelum perubahan penampang dengan variasi bukaan katup 100\%, 75\% dan 50\%. Hasil penelitian ini disajikan dalam bentuk grafik hubungan antara hasil 
penurunan tekanan terhadap bukaan katup yang divariasi. Sehingga didapatkan hasil penurunan tekanan yang terjadi di setiap bukaan katup dengan variasi 100\%, 75\% dan $50 \%$.

\section{Instrumen Penelitian}

Penelitian ini menggunakan instrumen peralatan dan bahan untuk melaksanakan penelitian, peralatan dan bahan yang digunakan terdiri dari pompa, bak penampung air, pressure gauge, pipa, tee, sambungan pipa, perubahan penampang mendadak dan katup. Berikut ini skema alat penelitian yang dapat dilihat pada gambar 2 .

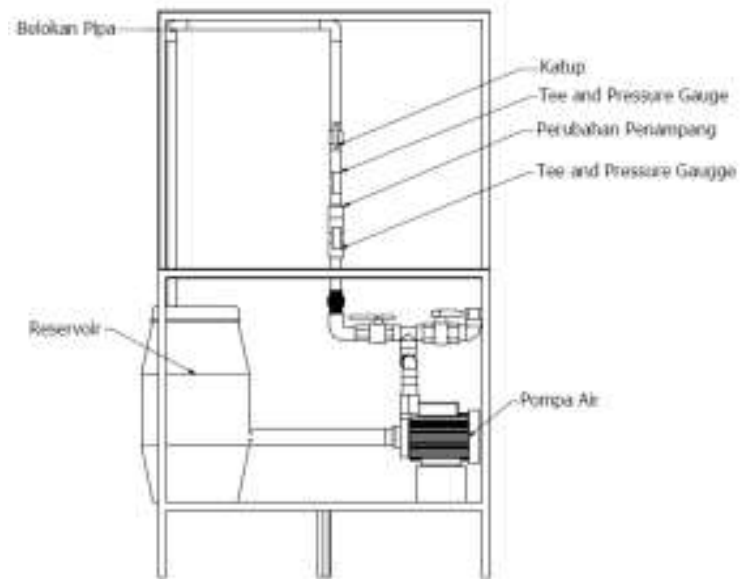

Gambar 2. Skema Instrumen Penelitian

Keterangan:

- Reservoir adalah bak penampung untuk menyimpan air. Bak penampung memiliki kapasitas 40 Liter.

- Pompa air yang digunakan merupakan pompa modifikasi dengan kapasitas \pm 100 Liter/menit.

- Pressure gauge yang digunakan memiliki kapasitas 1,5 bar dengan ketelitian 0,05 bar.

- Sistem perpipaan merupakan rangkain dari komponenkomponen pipa yang digunakan. Komponen tersebut yaitu pipa, percabangan pipa, belokan pipa, pengecilan dan pembesaran pipa. Ukuran sistem perpipaan yang digunakan yaitu 3/4 inci, 1 inci dan $1 \frac{1}{4}$ inci.

\section{Hasil dan Pembahasan}

Penelitian ini dilaksanakan di Laburatorium Teknik Mesin Universitas Hasyim Asy'ari Jombang. Penelitian ini menggunakan sambungan perubahan penampang 1 inci ke 3/4 inci dan 1 inci ke 1 $1 / 4$ inci dengan sambungan tee yang diletakkan pada sebelum dan sesudah perubahan penampang yang digunakan untuk alat ukur pressure gauge. Pengujian pertama yaitu pada perubahan pipa 1 inci ke $3 / 4$ inci dan dilanjutkan pengujian perubahan

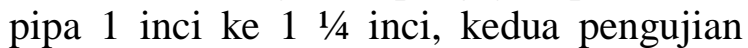
tersebut dilakukan sebanyak 3 kali pengujian. Maka, dari pengujian yang dilakukan diambil rata-rata pada semua pengujian yang dilakukan dan digunakan sebagai data hasil penelitian. Adapun hasil penelitian dapat dilihat pada Tabel 1 dibawah ini:

Tabel 1. Rata-rata hasil pengujian pressure

\begin{tabular}{|c|c|c|c|c|c|c|}
\hline \multicolumn{7}{|c|}{ Hasil Penelitian Pressure Drop } \\
\hline $\begin{array}{l}\mathrm{N} \\
\mathrm{O} \\
.\end{array}$ & $\begin{array}{c}\text { Nama } \\
\text { Komponen }\end{array}$ & $\begin{array}{c}\text { Buka } \\
\text { an } \\
\text { Katu } \\
\text { p }\end{array}$ & $\begin{array}{c}\Delta \mathrm{p} \\
1 \\
(\mathrm{ba} \\
\mathrm{r})\end{array}$ & $\begin{array}{c}\Delta \mathrm{p} \\
2 \\
(\mathrm{ba} \\
\mathrm{r})\end{array}$ & $\begin{array}{l}\Delta \mathrm{p} \\
3 \\
(\mathrm{ba} \\
\mathrm{r})\end{array}$ & $\begin{array}{c}\text { Rata- } \\
\text { rata } \\
\Delta \mathrm{p} \\
\text { (bar) }\end{array}$ \\
\hline \multirow{3}{*}{1} & \multirow{3}{*}{$\begin{array}{c}\text { Perubahan } \\
\text { Penampang } 1 \\
\text { Inci ke 3/4 Inci }\end{array}$} & $\begin{array}{c}100 \\
\%\end{array}$ & 0,1 & 0,1 & 0,1 & 0,1 \\
\hline & & $75 \%$ & $\begin{array}{c}0,0 \\
8\end{array}$ & 0,1 & 0,1 & 0,09 \\
\hline & & $50 \%$ & $\begin{array}{c}0,0 \\
3\end{array}$ & $\begin{array}{c}0,0 \\
5\end{array}$ & $\begin{array}{c}0,0 \\
5\end{array}$ & 0,04 \\
\hline \multirow{3}{*}{2} & \multirow{3}{*}{$\begin{array}{c}\text { Perubahan } \\
\text { Penampang } 1 \\
\text { Inci ke } 1 \text { 1/4 } \\
\text { Inci }\end{array}$} & $\begin{array}{c}100 \\
\%\end{array}$ & $\begin{array}{c}0,0 \\
3\end{array}$ & $\begin{array}{c}0,0 \\
5\end{array}$ & $\begin{array}{c}0,0 \\
0\end{array}$ & 0,03 \\
\hline & & $75 \%$ & $\begin{array}{c}0,0 \\
3\end{array}$ & $\begin{array}{c}0,0 \\
5\end{array}$ & $\begin{array}{c}0,0 \\
0\end{array}$ & 0,03 \\
\hline & & $50 \%$ & $\begin{array}{c}0,0 \\
5\end{array}$ & $\begin{array}{c}0,1 \\
0\end{array}$ & $\begin{array}{c}0,0 \\
3 \\
\end{array}$ & 0,06 \\
\hline
\end{tabular}

Berikut ini Pembahasan hasil penelitian pressure drop pada setiap perubahan penampang: 


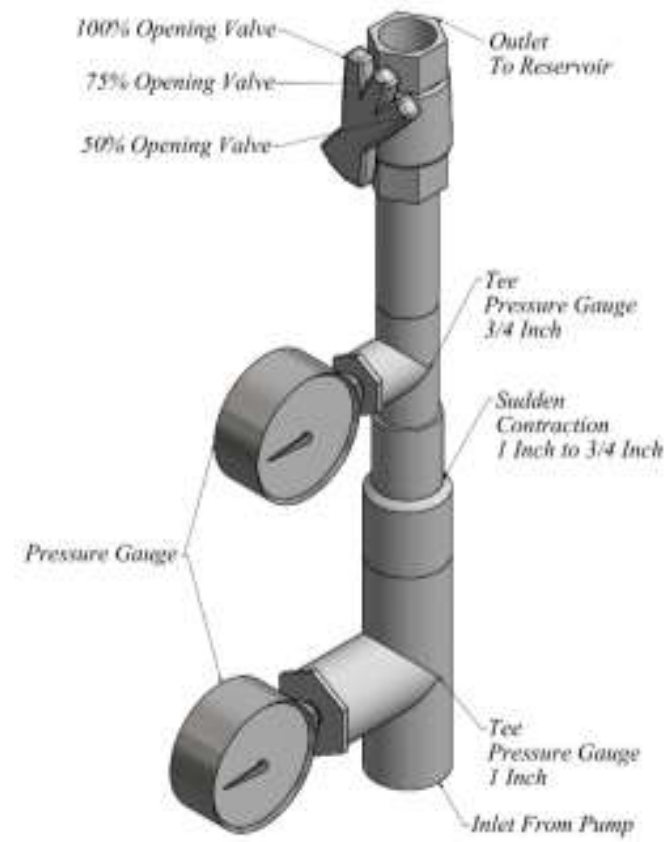

Gambar 3. Perubahan Penampang 1 Inci ke 3/4 Inci dengan Variasi Bukaan Katup

PRESSURE DROP PERUBAHAN PENAMPANG

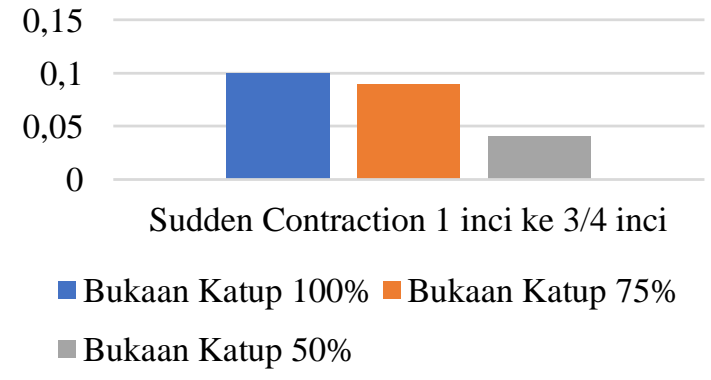

Gambar 4. Grafik Pressure Drop pada

Perubahan Penampang 1 Inci ke 3/4 Inci pada Setiap Bukaan Katup

Pada gambar 4 menunjukkan hasil pressure drop pada perubahan penampang 1 inci ke $3 / 4$ inci pada setiap variasi bukaan katup yang dapat dilihat pada gambar 3 . Nilai pressure drop terbesar terjadi pada bukaan katup $100 \%$ dengan nilai 0,1 bar, sedangkan nilai pressure drop terkecil terjadi pada bukaan katup 50\% dengan nilai 0,04 bar. Hasil dari gambar 4 menunjukkan nilai pressure drop semakin menurun seiring dengan semakin besarnya variasi bukaan katup. Hal tersebut terjadi karena dipengaruhi oleh kecepatan fluida yang turun karena kecilnya bukaan katup pada perubahan penampang pipa mendadak 1 inci ke $3 / 4$ inci.

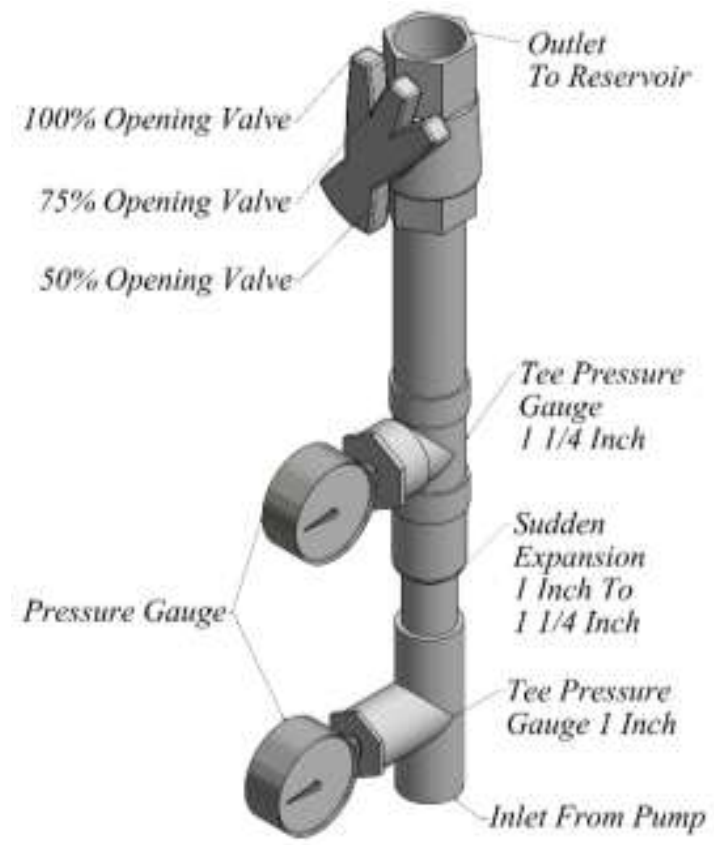

Gambar 5. Perubahan Penampang 1 Inci ke 1 1/4 Inci dengan Variasi Bukaan Katup

PRESSURE DROP PERUBAHAN PENAMPANG

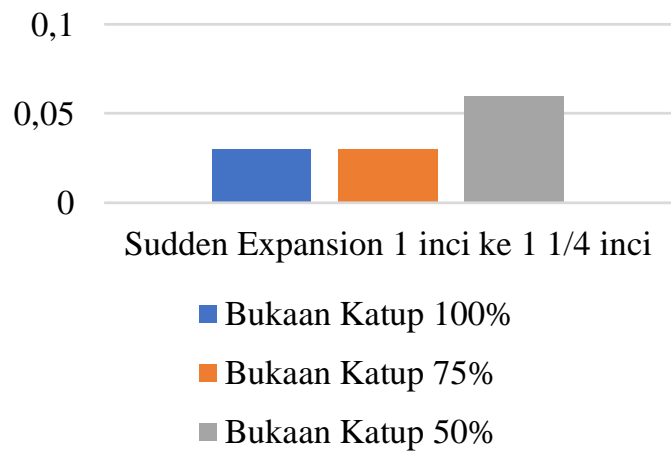

Gambar 6. Grafik Pressure Drop pada Perubahan Penampang 1 Inci ke 1 1/4 Inci pada Setiap Bukaan Katup

Pengujian pressure drop perubahan penampang pipa 1 inci ke $1 / 4$ inci yang dapat dilihat pada gambar 5 memiliki hasil yang dapat dilihat pada gambar 6 yaitu grafik pressure drop perubahan penampang 1 inci ke $1 \frac{1}{4}$ inci pada setiap variasi bukaan katup. Nilai pressure drop terbesar terjadi pada bukaan katup 50\% dengan nilai 0,06 bar, sedangkan nilai pressure drop terkecil terjadi pada bukaan katup $100 \%$ dan $75 \%$ dengan nilai 0,03 bar. Hasil dari gambar 6 menunjukkan nilai pressure drop semakin meningkat seiring dengan kecepatan aliran fluida yang turun karena kecilnya bukaan 
katup pada perubahan penampang pipa mendadak 1 inci ke 1 1/4 inci.

\section{Kesimpulan}

Berdasarkan hasil penelitian dan pembahasan tentang pengaruh perubahan penampang terhadap pressure drop pada setiap bukaan katup, dapat diambil simpulan bahwa pada perubahan penampang pipa mendadak 1 inci ke $3 / 4$ inci pada bukaan katup $100 \%, 75 \%$ dan $50 \%$, terjadi penuruan pressure drop apabila persentase bukaan katup semakin kecil. Nilainya yaitu 0,1 bar, 0,09 bar dan 0,04 bar. Pada perubahan penampang pipa mendadak 1 inci ke 1 1/4 inci pada bukaan katup 100\%, 75\% dan $50 \%$, terjadi peningkatan pressure drop apabila presentase bukaan katup semakin besar. Nilainya yaitu 0,03 bar, 0,03 bar dan 0,06 bar. Pada perubahan penampang 1 inci ke $3 / 4$ inci memiliki luas perubahan penampang yang lebih kecil, sehingga memiliki gesekan pada dinding pipa yang kecil. Hal tersebut membuat nilai pressure drop yang besar dibandingkan dengan pipa 1 inci ke $1 \frac{1 / 4}{4}$ inci yang luas perubahan penampangnya lebih besar.

\section{Saran}

Dari rangkaian penelitian diatas, maka dapat diberikan saran untuk penelitian selanjutnya. Beberapa saran dari penulis sebagai berikut:

1. Hendaknya alat disempurnakan lagi untuk mendapatkan hasil pengukuran yang lebih detail yaitu pada alat ukur pressure gauge dengan ketelitian yang tinggi atau pressure gauge digital.

2. Meneruskan penelitian dengan mengganti posisi perubahan penampang mendadak dipasang secara frontal/horizontal dengan perubahan penampang bertahap.

\section{Referensi}

[1] S. Z. Mohammad dan P. H. Adiwibowo, "Jurnal Teknik Mesin," Eksperimental
Pressure Drop pada Sambungan T (Tee) Contraction untuk Posisi Searah dengan Variasi Sudut Kemiringan, vol. 01, no. 03, pp. 7478, 2013.

[2] Lukman. 2011. Eksperimental Karakteristik Pressure Drop Pada Pipa Dan Variasi Elbow $90^{\circ}$ Untuk Sistem Perpipaan. Tugas akhir tidak diterbitkan. Surabaya: Jurusan Teknik Mesin FT-UNESA.

[3] Aufa, Ahmad. Rubiono, Gatut dan Mujianto, Haris. Pengaruh Rasio Diameter Pipa Terhadap Perubahan Tekanan Pada Bernoulli Theorema Apparatus, Vol. 1, No. 1, pp. 7-11, 2016.

[4] C. J. Geankoplis, Transport Processes and Unit Operations, New Jersey: Prentice Hall Inc., 1993. 